\title{
RADIOCARBON DATING OF EARTHQUAKES
}

\section{RAINER BERGER and THOMAS S KAUFMAN}

\author{
Institute of Geophysics and Planetary Physics, \\ Department of Anthropology and Geography, \\ University of California, Los Angeles, California
}

Within the United States, the State of California ranks first in recorded earthquake frequencies. Annually, thousands of shocks are registered on seismometers and many hundreds are actually noticed directly by Californians. In modern times, about one quake per year, destructive to property, has occurred, yet the very large and disastrous events approaching magnitude 8 and higher on the Richter scale are spaced a few decades apart: 1857 in Southern California centered on Tejon Pass, 1872 in the Owens Valley, and 1906 in San Francisco. Unfortunately, the historical record for earthquakes is short in California when compared with accounts for Europe or China, both of which list quakes over a time period of some 2000 to 3000 years. In California, the first historically noted event dates to barely 200 years ago, when in 1769 , members of an expedition of the Spanish explorer Gaspar de Portola were knocked to the ground along the Santa Ana River during a large earthquake.

The largest and longest of the geologic faults in California is the San Andreas Fault which slices in a southeasterly to northwesterly direction through California for a distance of about $1000 \mathrm{~km}$. It originates in the Gulf of California and terminates again under water in the GordaMendocino escarpment. The San Andreas is of the right lateral displacement type separating the North Pacific and North American tectonic plates. Extensive geologic studies over the years show that the land mass west of the fault slowly moves northwestward relative to North America at an average rate of some $5 \mathrm{~cm} /$ year (Anderson, 1976). During this process, many earthquakes occur or have taken place, notably, the 1857 event in Southern California and the destruction of San Francisco in 1906. In connection with the intermittent motion of the San Andreas system, much geomorphologic change has transformed the adjacent landscape (Iacopi, 1976). Besides well-publicized lateral displacements, extensive vertical shifts have also occurred in the geologic past, as much as a total of some $4000 \mathrm{~m}$ in the San Bernardino and San Jacinto Mountains.

In recent years, considerable concern has arisen whether or not a disaster of the magnitude of the San Francisco earthquake might happen again in a populated area of the state. The following realization emphasizes the acuteness of the problem: during the 1906 San Francisco event, total lateral displacements on the order of 4 to $6 \mathrm{~m}$ were observed. If the fault system moves on the average at $5 \mathrm{~cm} /$ year, then after a century, sufficient strain should have accumulated in the rocks below to again result in a major quake with surface displacements of that magnitude. Such estimates have resulted in a major acceleration of earthquake research in California. 
From the point of view of earthquake prediction, the best possible understanding of past events over as long a time as possible is fundamental to the formation of adequate hypotheses, theories, and ultimate control of data. However, as explained above, barely some 100 to 200 years worth of information exists. Thus, it became imperative to try to unravel the prehistory of major California earthquakes. Over the last 15 years or so, the Isotope Laboratory of the Institute of Geophysics at UCLA has been engaged in the radiocarbon dating of organic materials found in geologic fault zones. This research in effect proved that suitable materials exist in nature. For example, during movements along a fault, organic material such as wood can become entrained and survive for long periods of time. Another often observed effect results from the ponding of streams which produces peat-like deposits datable by ${ }^{14} \mathrm{C}$. Recently, Sieh (1977) has shown how displacements in organic-rich sedimentary layers can be analyzed to provide radiocarbon dates for the time when an earthquake produced the respective fault trace. However, such locations do not always exist inasmuch as geology or climate may be unsuitable for the formation or retention of a precise sedimentary record.

It has been observed that significant surface ruptures and displacements are often associated with earthquakes of moderately destructive magnitude on the order of events measured as Richter Scale 5-6 or above. However, there are exceptions to this, since the 1940 Imperial Valley quake of only 3.6 magnitude produced a roughly $45 \mathrm{~cm}$-long offset in the highway between El Centro and Holtville, California (S80). In general, surface fracturing results in the formation of a series of long and narrow ridges separated by troughs which is most noticeable in a fault-controlled valley. Yet, even more common are scarps made by sudden horizontal or vertical motions which exist by the hundreds along the San Andreas Fault. Sometimes a severe earthquake may squeeze rock between two parallel faults upward into a long slender pressure ridge or even cause a portion of a mountain to break away and begin to move along the tectonically active zone with each subsequent quake. This slicing action, of course, affects trees growing on the surface so that they become buried in the ensuing geomorphologic upset. The occurrence of landslides along the San Andreas has been attributed to two major factors. First, steep slopes of hills and mountains provide for potentially unstable conditions, and second, extensive fracturing of rock by cracks and major breaks permits water to reach deep into the affected mass and turn it into a slide area. Due to the right lateral motion of the San Andreas, rivers and streams crossing the fault zone at right angles will become offset in a roughly Z-shaped manner. The leg between the distal ends of the " $Z$ " becomes progressively longer with continuing fault motion. Last but most important, sag ponds develop in a zone experiencing active faulting. These depressions exist by the hundreds along the San Andreas where they have been caused by displacements. They become ponds and plant communities establish themselves, serving as sources of organic deposits datable later by radiocarbon. The formation 
of such a sag area was directly observed immediately after the recent earthquake on the Imperial Fault (15 October 1979; Richter Scale 6.5) near Heber, California.

The question may be raised to what extent tectonic displacements are always accompanied by earthquakes, or if there is actually observed slow creeping motion not associated with shocks at all (Aseismic Slip; Bolt, 1978). A famous case in point is the Almaden Vineyards warehouse in the Hollister area where creep not necessarily associated with notable quake activity is slowly pulling the building apart. Yet, this motion is intermittent in character, taking place in week-long episodes separated by pauses of a week to month-long durations. The rate of displacement averaged over the time the measurements began is on the order of about a centimeter per year. Consequently, it can be argued that very slow rates of motion may not be associated with quake activity at all. Either the rocks are able in a variety of ways, to dissipate the energy imparted to them such that no quake will occur, or the build-up is so slow that, after some time, a major dislocation occurs. On the other hand, substantially faster rates of slippage averaged over the time of their measurement appear to be coupled with quakes as the effective displacement reaches several centimeters per year. Rocks are apparently unable to

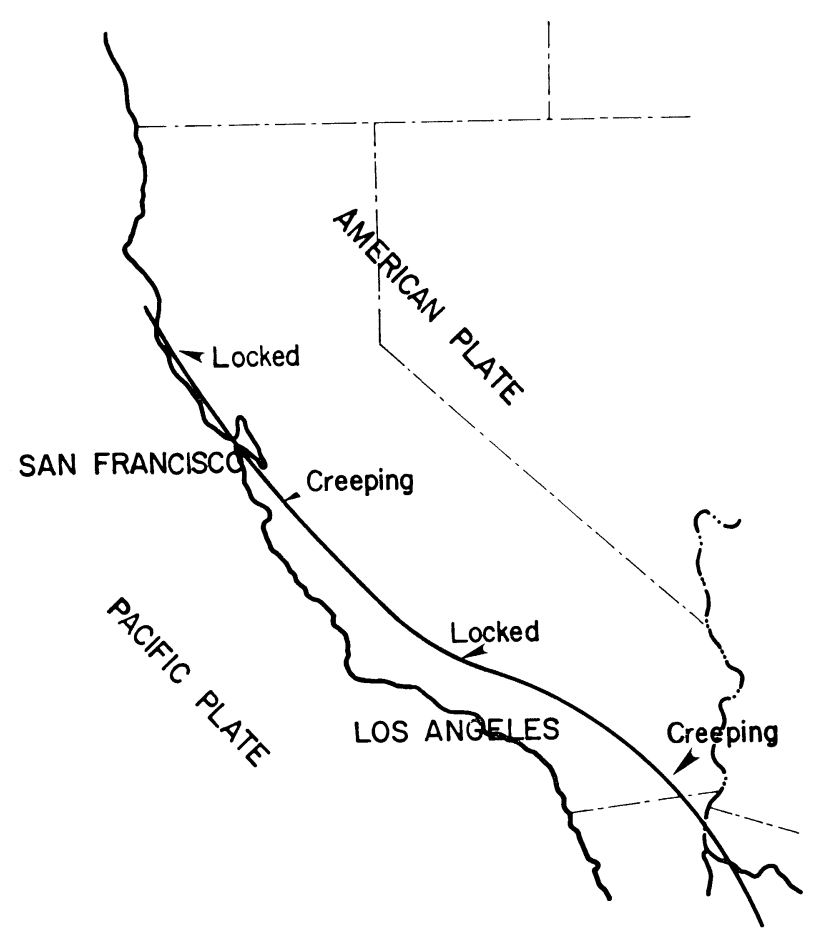

Fig 1. Map of California showing active and quiescent regions along the San Andreas Fault. 
dissipate the energy at the rate produced, and they release it in the classic elastic rebound mode. In figure 1, those sections of the fault are marked which are now known to be experiencing creep, or no motion for the last 60 to 70 years, as witnesses have reported.

From these observations and some of the data below, it appears that at any given time motions along the San Andreas occur at different rates. Many stresses are obviously accommodated by the very complex system of other faults coupled to the main course of the San Andreas. Besides the horizontal strike-slip action, thrusting takes place such as in the San Fernando quake of $1971 \quad(M=6.5)$, when portions of the San Gabriel Mountains were allegedly thrust upward by as much as a few meters.

This research has been aimed at the radiocarbon dating of geologically recent displacements along the San Andreas Fault. In particular, we seek to determine the recurrence rates of major prehistoric earthquakes. Most of our research has been concentrated on the stretch from Cajon Pass $\left(34^{\circ} 20^{\prime} \mathrm{N} ; 117^{\circ} 25^{\prime} \mathrm{W}\right)$ to the Parkfield area $\left(35^{\circ} 55^{\prime} \mathrm{N} ; 120^{\circ}\right.$ $25^{\prime} \mathrm{W}$ ). Many of the locations have been previously described by geologists and seismologists and appear in the general literature, with much credit belonging to Clarence Allen and other members of the California Institute of Technology, members of the US Geological Survey, the California Division of Mines and Geology, and the University of California.

The first location dated is Lost Lake near Cajon Pass, where a sag pond was created by movements along the fault, also resulting in a substantial offset of a small seasonal mountain stream (pl 1). From the moment this depression was formed it was invaded by plants that died off after their life-cycle, creating an organic layer at the base of the pond. By trenching with a mechanical back-hoe, the lowest organic level was reached at a depth of $1.40 \mathrm{~m}$. At the same time, the geologic profile of the trench was recorded. However, the sedimentary record is not very detailed. It consists largely of a thick humus/peat layer containing smallgrained granitic debris until sterile bottom is reached, which, in turn, is composed of coarse-grained granitic clastics.

Two samples for radiocarbon dating from the lowest organic level were collected and analyzed at UCLA. After mechanical separation of organic and inorganic materials, the former were treated in succession with dilute hydrochloric acid and sodium hydroxide. The $\mathrm{CO}_{2}$ derived from the sample was counted in a $\mathrm{CO}_{2}$ proportional counter. The ages of the samples were $1050 \pm 80$ and $1205 \pm 80$ years, respectively (UCLA2065 and -2069). If the mean of these two measurements were taken and the date calibrated against the tree-ring sequence used by Suess (1979), the age that Lost Lake was first created by a tectonic event would be AD 800 .

Also associated with Lost Lake is a major stream offset of the characteristic " $Z$ " type. The drainage of the overflow of Lost Lake has cut a channel into the main mountain stream bed at a point $85 \mathrm{~m}$ from its next $90^{\circ}$ turn downhill (fig 2). A simple calculation shows that the displacement rate along the fault in this location is $8 \mathrm{~cm} /$ year averaged 
Plate 1

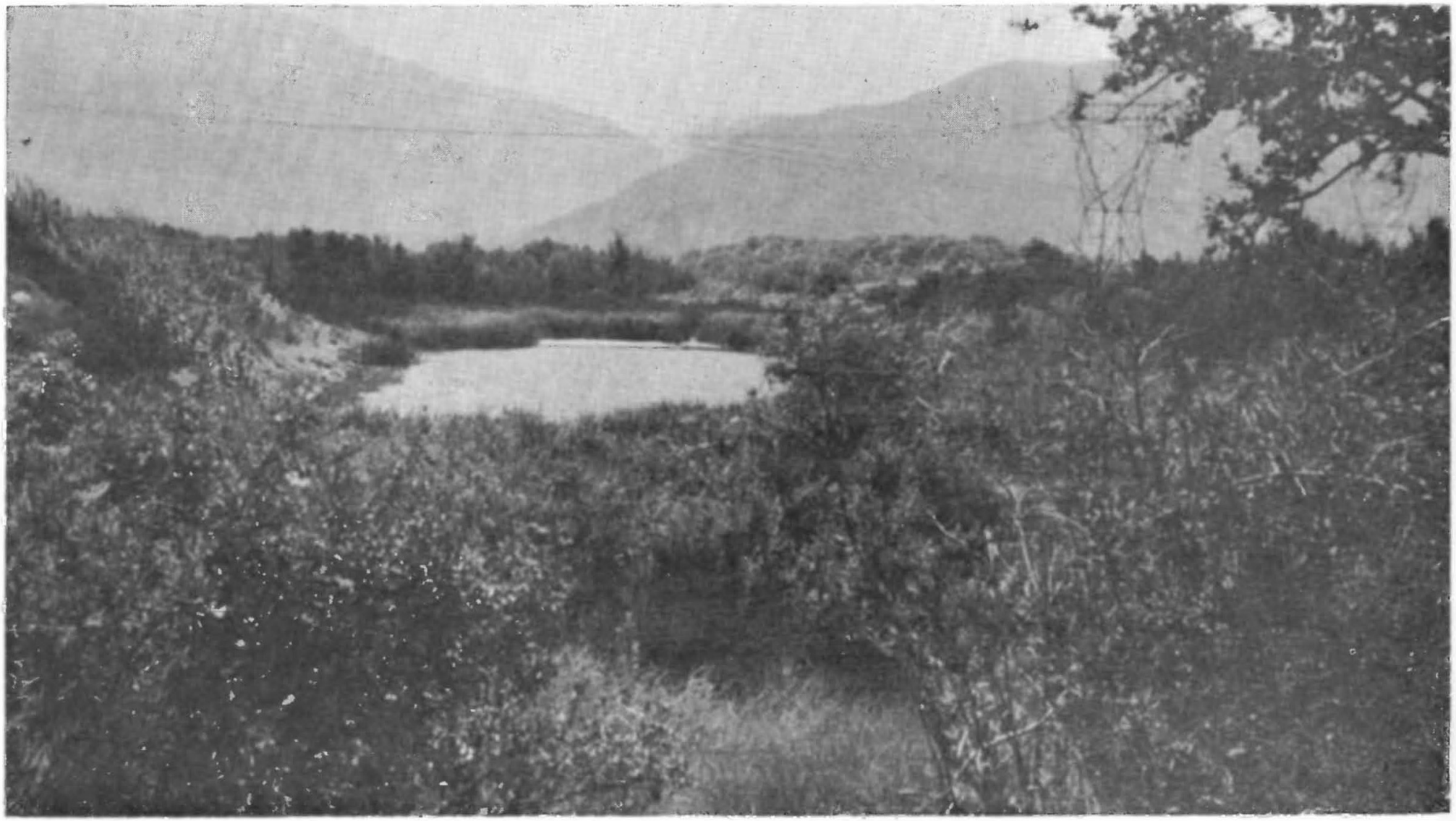

Lost Lake located on the San Andreas Fault, Cajon Pass, California. 
over about 1000 years. Since the excavation reached deeper than the last organic stratum and no further organics were found below, this relatively high rate of average slip must be correct. As a result, the course of the fault between Cajon Pass and Wrightwood must be regarded as a very active section. Yet, during the last 10 years or so, no particular displacements have been noted either in the rail links climbing through Cajon Pass, the freeway (Interstate 10), or high voltage transmission lines.

The next location dated is a scarp composed of finely crushed granite near the Apple Tree Campground (Highway N4, west of Wrightwood). Fault action has pulverized granite that makes up the sub-surface rock of the area (pl 2).

Partially buried tree trunks datable by radiocarbon are found in the fine powder. Some of the tree trunks were deeply buried under tons of whitish debris which is only possible if existing trees were covered by subsequent fault action. One of the lowermost buried trunks was dated at $395 \pm 80$ years old (UCLA-2061), or about AD 1600 when tree-ring calibrated after Suess (1979). The date marks the dislocation and burial of this particular tree trunk and does not necessarily imply that later additional fault action may have occurred in the area.

Since sag ponds can be easily converted into water reservoirs or swimming ponds, several in the region between Wrightwood and Valyermo were modified by engineering work. The degree to which the lowest organic sediments of these sag areas have remained undisturbed has become suspect. Consequently, they were not further investigated or dated.

Lake Elizabeth $\left(34^{\circ} 40^{\prime} \mathrm{N} ; 118^{\circ} 25^{\prime} \mathrm{W}\right)$ is a very large sag pond, somewhat modified in certain areas. Excavation with a back-hoe yielded

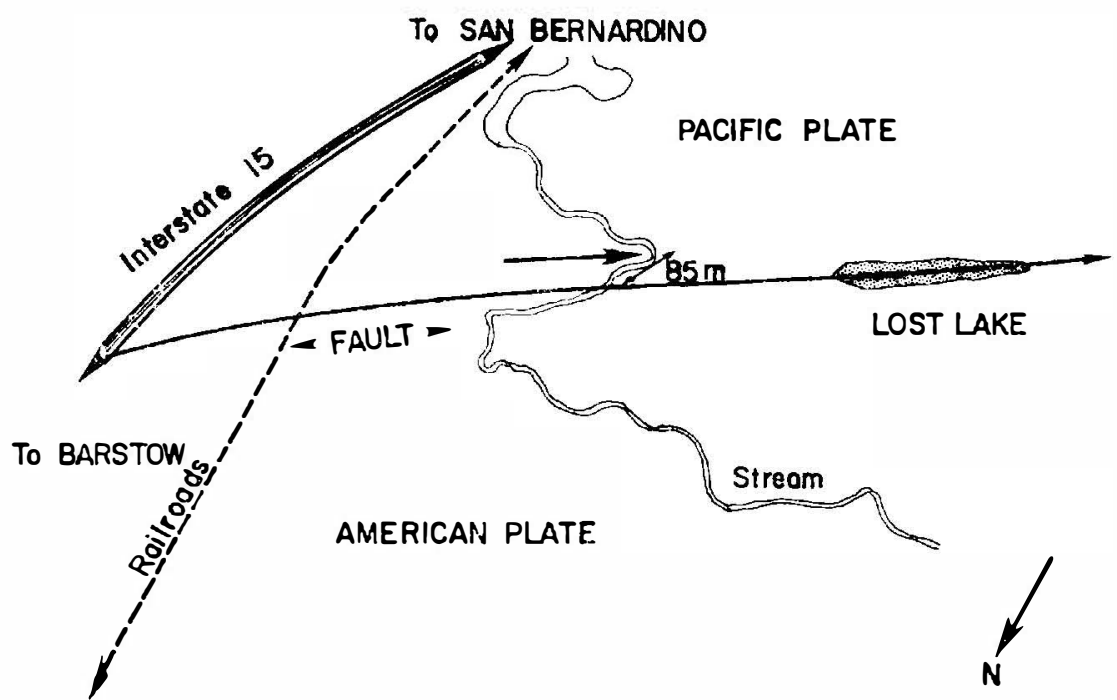

Fig 2. Displaccment of seasonal mountain stream near Lost Lake, Cajon Pass, California. 


\section{PLATE 2}

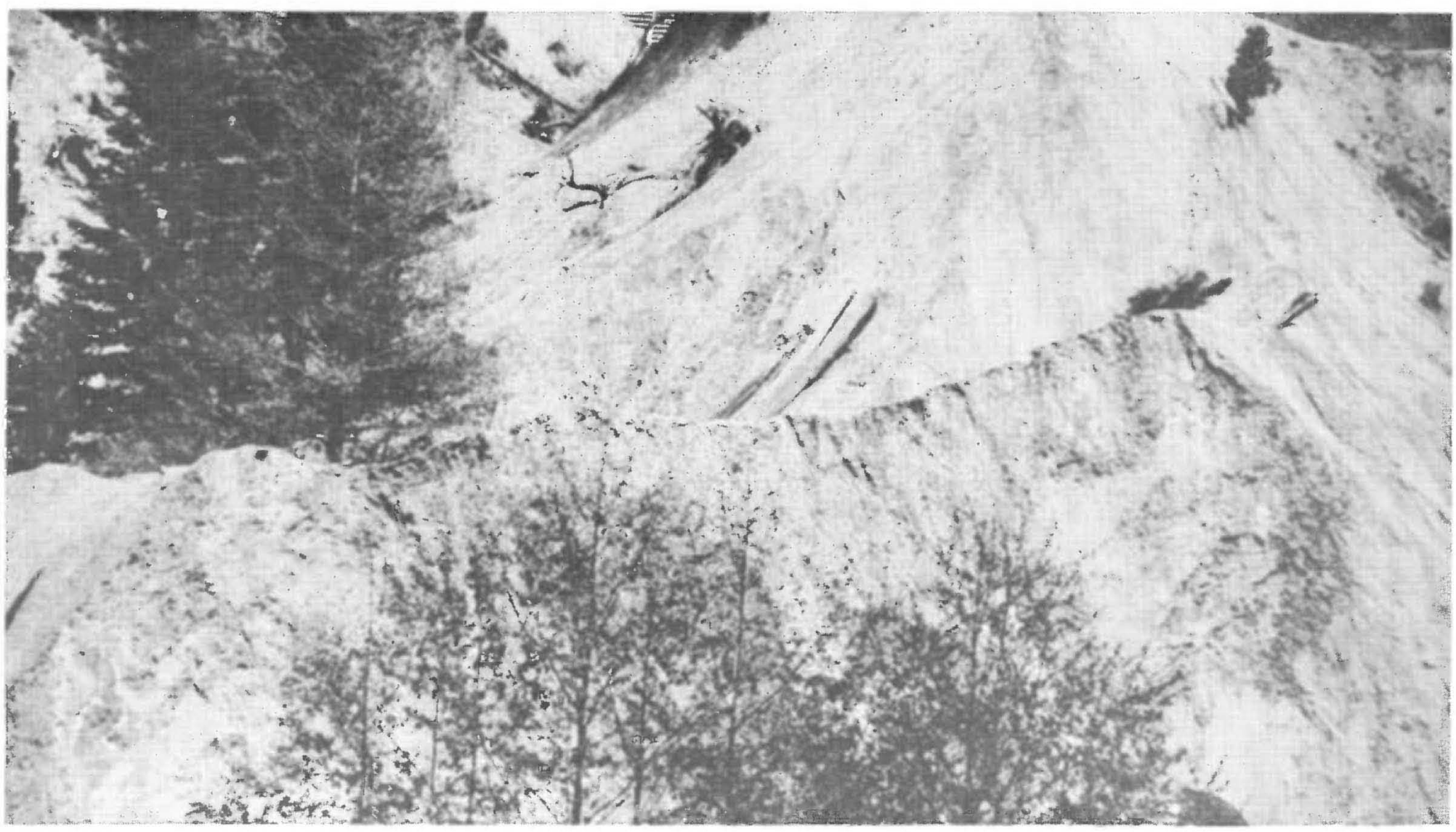

Scarp composed of finely ground granite near Apple Trec campground west of Wrightwood, California. 


\section{PLATE 9}

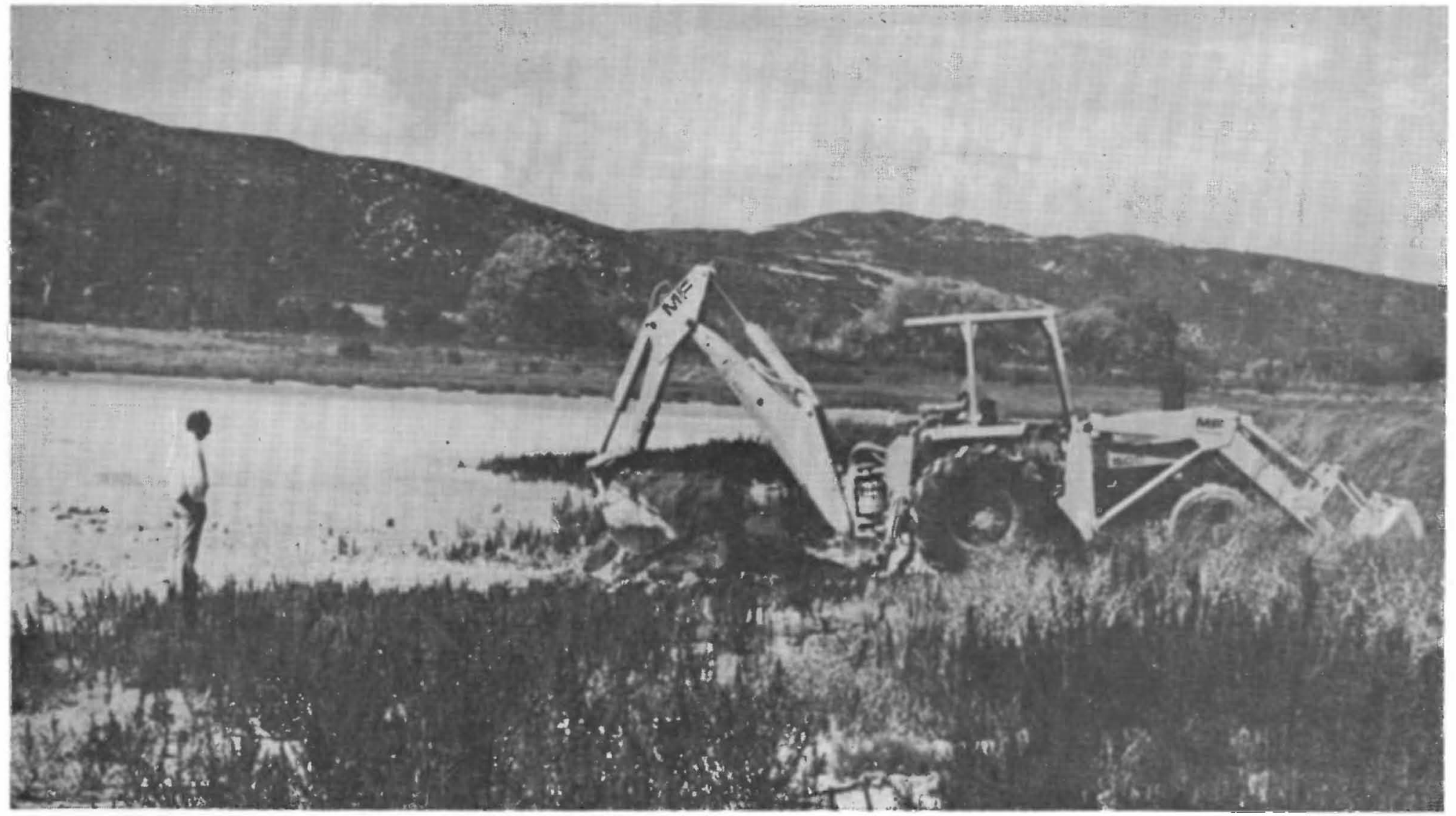

Trenching operations on margin of Elizabeth Lake, California. This sag pond virtually dried during the fall, 1977. 
PLATE 4

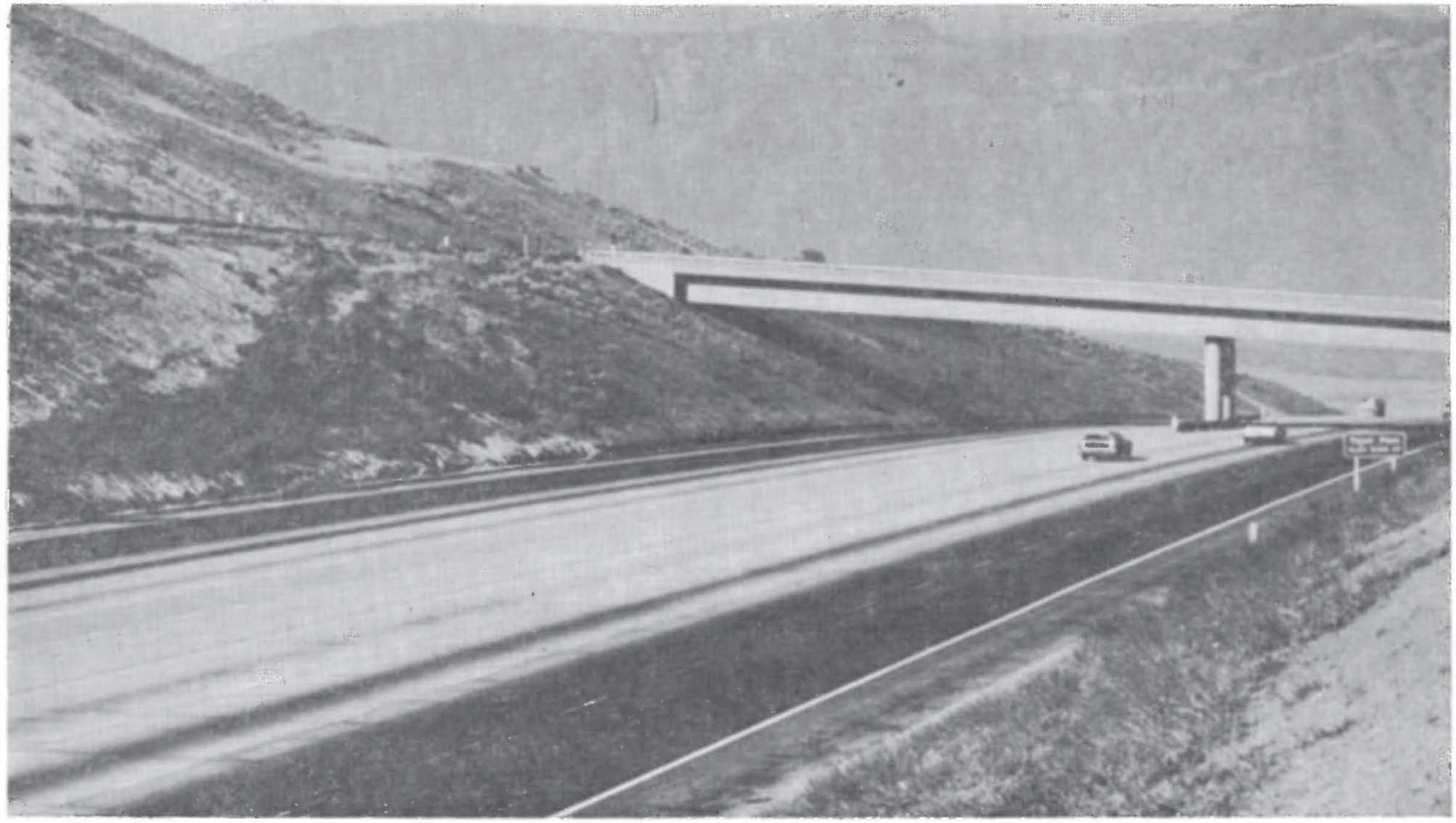

Location of buried trec trunks at Tejon Pass, California. Wood was collected near sign (center left) on Interstate 5. 
organic sediments at two locations. The lowest organic level above granitic clastics was encountered at $2.40 \mathrm{~m}$ below the surface. Again, no distinctively discrete sedimentation pattern was observed, except that the concentration of organic material was much less than at Lost Lake. The samples were processed in the same manner. The calibrated radiocarbon age for the appearance of the first organic horizon and, therefore, the first appearance of Lake Elizabeth is about AD 100 (UCLA-2072) (pl 3).

Near Gorman $\left(34^{\circ} 48^{\prime} \mathrm{N}, 118^{\circ} 50^{\prime} \mathrm{W}\right)$ a sag pond area was excavated by trenching in the usual manner. High ground water levels made it impossible to penetrate to any great depth. However, a fence post containing square-stemmed iron nails was discovered at a depth of $1.50 \mathrm{~m}$, the wood dating from about AD 1600 (UCLA-2081). If the wood used to make the fence post was a few hundred years old, then the post itself may have been entrained during the great 1857 earthquake which caused severe damage in the area.

At the summit of Tejon Pass $\left(34^{\circ} 49^{\prime} \mathrm{N}, 118^{\circ} 54^{\prime} \mathrm{W}\right)$ altitude, $1240 \mathrm{~m}$, construction of Interstate 5 cut through an ancient massive landslide, a phenomenon quite common in this region. Geologists for the California Department of Transportation noted a score of tree trunks buried in clastics. Many remnants are still preserved today in the free-way cut (pl 4). Since the wood is a variety of cedar that does not exist in the immediate area, suspicion arose that the slide might be of Pleistocene age, a time when the surrounding mountains were heavily forested. After pretreating the wood by standard methods, including hydrochloric acid and sodium hydroxide immersion, it was dated in the UCLA proportional counter to over 40,000 years old (UCLA-2036A and B). A suffciently large sample was then sent to the isotopic enrichment facility at Groningen where W G Mook's team determined two ages: 41,700 \pm 800 and 41,850 \pm 120 years (GrN-8566 and -8581). This sample indicates that wood, under the right environmental conditions, can be preserved from the distant past and can date a massive ancient landslide. Moreover, different chemical treatments did not produce significantly deviant ages which attests to the accuracy of the determination. Regarding the coincidence of earthquake and slippage, it should be remembered that radiocarbon dates are associated with statistical errors of a magnitude that should take into account any delay between fault motion and water saturation of a land mass resulting in a slide.

At the time of this writing, several sag pond deposits have been processed and await final analysis. The samples stem from the Southern Carrizo Plain near Camp Dix and the Northern Cholame Valley area. The results of these analyses will be published elsewhere.

Temporal correlations between distant geographic locations dated along the fault have not as yet been established. During the 1906 San Francisco event, surface ruptures occurred over a distance of some $300 \mathrm{~km}$ from San Juan Bautista $\left(36^{\circ} 50^{\prime} \mathrm{N}, 121^{\circ} 34^{\prime} \mathrm{W}\right)$ in the south to Pt Arena $\left(38^{\circ} 54^{\prime} \mathrm{N}, 123^{\circ} 40^{\prime} \mathrm{W}\right)$ in the north. Similarly, the 1857 Tejon earthquake also saw widespread dislocations over great distances. 
Furthermore, the northern San Andreas Fault was explored by surface reconnaisance using USGS Miscellaneous Geologic Investigations Maps I-575 (Brown, 1970), MF-650 (Sarna-Wojcicki, Pampeyan and Hall, 1975) and I-692 (Brown and Wolfe, 1972). During these field trips, a considerable number of sagponds and other features were located, which were directly related to fault activity and amenable to radiocarbon dating.

Besides the studies along the San Andreas Fault proper, other dating research was conducted along faults in the Pasadena and Lake Castaic area. The results of those investigations will be reported elsewhere.

\section{ACKNOWLEDGMENTS}

We thank W F Libby for his active encouragement and support. $\mathrm{R}$ Bagby, L Biehl, A Campo, J De Facio, R M Johnson, D Knittel, M Rudnick, and members of the US Forest Service assisted greatly during field operations. This is publication number 1980, Institute of Geophysics and Planetary Physics, UCLA, supported by the National Science Foundation.

\section{REFFRENCES}

Anderson, D L, 1976, The San Andreas Fault, in Continents adrift and continents aground: San Francisco, Freeman and Co, Sci Am pub.

Bolt, B A, 1978, Earthquakes: San Francisco, Freeman and Co, p 46.

Brown, R D, Jr, 1970, Map showing active breaks along the San Andreas and related faults between the northern Gabilan range and Cholame Valley, California: US Geol Survey, Misc Geol Invest Map I-575.

Brown, R D, Jr and Wolfe, E W, 1972, Map showing recently active breaks along the San Andreas Fault between point Delgada and Bolinas Bay, California: US Geol Survey, Misc Geol Invest Map I-692.

Iacopi, R, 1976, Earthquake country: Menlo Park, Lane Books.

Sarna-Wojcicki, A M, Pampeyan, E L, and Hall, N T, 1975, Map showing recently active breaks along the San Andreas Fault betwcen the central Santa Cruz Mountains and the northern Gabilan Range, California: US Geol Survey, Misc Field Studies Map MF-650.

Sich, K E, 1977, A study of Holocene displacement history along the south-central reach of the San Andreas Fault: Doctoral dissert, Stanford Univ.

Suess, H E, 1979, A calibration table for conventional radiocarbon dates, in Berger, Rainer and Suess, H E, eds, Radiocarbon dating, Internatl radiocarbon conf, 9th, Proc: Berkeley/Los Angeles, Univ California Press, p 777-784. 